\title{
Kritik nr. 205, oktober 2012
}

Redigeret af Frederik Stjernfelt og Lasse Horne Kjaldgaard.

Pris lossalg (1 nummer) kr. 150; abonnement (pr. årgang, 4 numre) k.r. 500.

Kritik nr. 205 er, som det så ofte er tilfældet med Kritik, en interessant rodebunke af artikler om en række vidt forskellige emner. Nummeret indledes med Søren Schous veloplagte introduktion til og diskussion af Søren Ulrik Thomsens essaystik. Derefter følger Karl Heinz Bohrers noget mere adstadige analyse af Dionysos-figurens betydning for udviklingen af, hvad Bohrer kalder for "tilsynekomstens æstetik". Bo Kampmann Walther kaster sig derefter modigt ud i (det velsagtens umulige projekt) at give en introduktion til og et overblik over forholdet mellem narrativitet, tid og transmedialitet i tv-serien Lost. Det lykkes forbløffende godt, men hvis man ikke har set serien, så er det formodentligt umuligt at forstå og følge Walthers artikel.

Bent Holm leverer en interessant analyse af, hvorledes 1500og 1600-tallets europæiske italesættelse af "Tyrkeren" påvirkede og komplicerede datidens tilgang til og forståelse af Shakespeares Othello. Dan Zahavi giver en kort og klar indføring i Husserls empati-begreb, og diskuterer hvorvidt og i hvilken forstand Husserls teori understøtter og/eller understøttes af nyere neurofysiologi, mere specifikt opdagelsen af de såkaldte "spejl-neuroner". Claus Bryld diskuterer forholdet mellem (disciplinen) historie og den (levede) erindring med udgangspunkt i begrebet om "kollektiv erindring" og de senere års forskning i de såkaldte "erindringssteder". Og Per Aage Brandt præsenterer på blot fire sider ikke blot et nyt kulturbegreb, men også en ny måde at tænke om sandhed, magt og kulturel udvikling. Det er imponerende men ikke just overbevisende gjort.

Frem for at gå nærmere ind på alle de ovenstående artikler, vil jeg her i stedet fokusere på nummerets fire afsluttende artikler, som redaktørerne har samlet $\mathrm{i}$ en fælles temadel under overskriften "Tegneseriens æstetik". Tre af artiklerne bygger på foredrag holdt ved et endags seminar, "The Aesthetics of Comics" der blev 
afholdt i Aarhus i december 2011. Den fjerde artikel, der måske snarere har karakter af en note, er forfattet til dette nummer af Kritik. Artiklerne giver, på hver deres måde, en indføring i forskellige (forsknings)teoretiske tilgange til studiet og forståelsen af tegneserier, et område der i netop disse år er i hastig, ja man kan måske næsten sige eksplosiv, vækst.

Temadelen indledes med Felix Kühn Paulsens korte (31/2 sides) indlxg "Formens muligheder: Lille note om tegneserier og diagrammer", der er skrevet specifikt til Kritik. Paulsens tese er, at (i det mindste visse typer af) tegneserier med fordel kan betragtes og analyseres som (en form for) diagrammer. Både tegneserier og diagrammer er således karakteriseret ved, at de simultant kan repræsentere flere tider og steder på én flade, noget der klart adskiller tegneserien fra f.eks. film, litteratur og billedkunst. Og i det mindste visse diagrammer kan siges at benytte tekst og tegninger til at udtrykke en fortælling, dvs. repræsentere et $\mathrm{i}$ tid og rum udspændt handlingsforløb, noget der på slående vis minder om tegneseriens formsprog. I sin note søger Paulsen at uddybe og begrunde sin tese gennem en sammenligning af en side fra Chris Wares vidt berømmede Jimmy Corrigan: Den klogeste dreng i verden, og et diagram over dødsfaldene under Napoleons felttog mod Moskva. Om det lykkes? Tjah, det er op til læseren at bedømme.

Nikolaj Zeuthen (hvis tegneserie "Hvad synes du om dansk litteratur" i 2010 blev præmieret af Statens Kunstfonds Litteraturråd) giver under overskriften "C'mon kid - get in there and FIGHT?" hvad han selv i en undertitel betegner som et "Robert Crumb-crashcourse for begyndere og let øvede". Zeuthen samlæser Crumbs liv og værk og giver en meget personlig og engageret introduktion til den amerikanske undergrundstegneseries mest betydningsfulde og indflydelsesrige kunstner.

I samme omgang leverer Zeuthen desuden en form for diagnose af tegneseriemediets (manglende?) kunstneriske selvforståelse. Hvad der kendetegner Crumbs kunstneriske virker er nemlig ifølge Zeuthen, at "Han har forstået hemmeligheden ved tegneserien som kunstnerisk medie: at den altid i udgangspunktet er undseelig; en lavkulturel hybridform man først og fremmest skal grine af. De store emner kommer man til nedefra." (s. 110). Det er uklart om 
dette også er Zeuthens egen opfattelse, men det virker umiddelbart sådan. Man kunne godt have ønsket sig denne pointe uddybet og yderligere diskuteret. Som analytisk udgangspunkt for Zeuthens tilgang til og analyse af Crumbs livsværk virker det som en tilforladelig tese. Spørgsmålet er imidlertid, om den kan (og bør) udbredes til en generel karakteristik af tegneserien som kunstnerisk medie perse.

Rikke Platz Cortsens "Få styr på dine niveauer! Om tid og rum i tegneserier" er uden sammenligning den teoretisk mest spændende, men samtidig også sværest tilgængelige, af temadelens fire artikler. Artiklen trækker på og sammenfatter en række pointer fra Cortzens ph.d. afhandling, der handlede om (forholdet mellem) tid og rum i tegneserier. Cortsens grundlæggende pointe er, at de dominerende teoretiske tilgange til denne problematik er præget og plaget af manglende begrebslig klarhed og differentiering.

Med udgangspunkt i to idealtypiske tilgange "I tegneserier er tid og rum klart adskilte" og "I tegneserier er tid og rum det samme" argumenterer Cortsen vha. konkrete eksempler for, at begge disse tilgange er problematiske og mangelfulde. Det væsentlige og interessante spørgsmål er ifølge Cortsen ikke, om tid og rum er identiske eller om de tværtimod er klart adskilte størrelser, men snarere hvordan og på hvilke måder tid og rum rent faktisk sammenknyttes i konkrete værker. For at begrebsliggøre og illustrere denne pointe udvikler Cortsen en kompleks 4-plansmodel over tid og rum i tegneserier, som muliggør en teoretisk uddifferentiering og adskillelse af tid og rum på flere forskellige niveauer: Fortællingens, strukturens (jeg ville nok sige værkets), læserens og den virkelige verdens.

Præsentationen af denne model lider desværre en smule under, at Cortsen benytter tal og bogstaver til at betegne tid og rum på de forskellige niveauer, hvilket i sammenhæng med artiklens generelle akademiske sprogbrug leder til svært forståelige sætninger som disse: "Læseren forestiller sig den tidslige progression T1 ved hjælp af forholdet T1-R1 og forholdet T2-R2 og ved konkret at bevæge sig igennem T3-R3, det vil sige ved at læse. Evnen til at forestille sig tid og rum udspringer af læserens erfaring med tid og rum i T4-R4. Spatiotemporaliteten T1-R1 er en fiktiv tid-rumlig konfiguration, men den er også en konfiguration der beror på erfaring” (s. 119). Pyh! 
Det er et af tegneserieforsknings grundlæggende spørgsmål, som Cortsen tager op i sin artikel, og hun bryder ny grund med sin teoretiske uddifferentiering og eksplicitering af de forskellige niveauer, hvor tid og rum gør sig gældende i tegneserier. Det er derfor ikke noget under, at hendes fremstilling visse steder er en smule utilgængelig. Men det er så afgjort værd at bruge tid og kræfter på Cortsens artikel, da hendes tilgang potentielt set kan (op)løse en række af de teoretiske problemer og diskussioner, som tegneserieforskning traditionelt har bakset med.

Temadelen afsluttes med Frederik Stjernfelt og Svend Østergaards artikel "FONK! HONK! WHAM! OOF! Repræsentation af begivenheder hos Carl Barks - og i tegneseriens æstetik generelt". Det problem som Stjernfelt og Østergaard her tager op er, hvorledes dynamiske tidsforløb, in casu handlinger og begivenheder, repræsenteres i tegneseriemediets statisk-visuelle udtryksform. For at besvare dette spørgsmål vender Stjernfelt og Østergaard sig (ikke overraskende) mod den kognitive lingvistik. Deres tese er, at "såvel forståelsen af sprog som aflæsning af billeder beror på de samme grundlæggende kognitive principper for, hvordan mennesket skaber betydning" (s. 125). På denne baggrund, og med eksempler hentet fra Carl Barks' verdensberømte Anders And historier, opstiller Stjernfelt og Østergaard fem overordnede regler for, hvordan tegneseriemediet kan og må repræsentere handlinger og begivenheder, så en læser kan forstå og fortolke det repræsenterede netop som handlingsforløb.

Stjernfelt og Østergaard har fat i en central problemstilling, og kommer i deres artikel også med flere interessante overvejelser. Desværre lader deres overordnede tilgang til og forsøg på at løse problemet om handlingsrepræsentation i tegneserier en del tilbage at ønske. Lad mig her blot nævne et par enkelte forhold.

For det første så rummer deres artikel ingen referencer til den eksisterende tegneserieforskning, på trods af at de gentagen gange kommenterer på og udtaler sig om denne forskning. Mest bemærkelsesværdig er nok, at Scott McClouds begreb om "closure" ikke diskuteres, på trods af at Stjernfelt og Østergaard i en note (note 4) synes at diskutere og gøre op med præcis denne forståelse af, hvordan tegneserielæsere forbinder enkelte tegneseriepaneler med hinanden $\mathrm{i}$ meningsgivende helheder. 
For det andet så er der god grund til at stille sig tvivlende overfor en af de helt centrale påstande i Stjernfelts og Østergaards artikel: Tesen om at alle mennesker har en fælles, medfødt evne til at aflæse billeder på samme måde. Som Stjernfelt og Østergaard formulerer det: "Intet barn har brug for en eksplicit instruktion i, hvordan billederne [i en tegneserie] skal forstås, for eksempel at en serie af billeder henviser til den samme begivenhed, selv om mellemled kan være udeladt, og så videre” (s. 125). Dette er en påstand som i artiklen ikke begrundes hverken empirisk eller teoretisk. Og det er en påstand, som der kan være grund til at forholde sig kritisk til. For vesterlændinge der ikke er vokset op med manga kræver det f.eks. øvelse, nogle gange eksplicit instruktion, at læse og forstå den japanske tegneseriefortællestil. Og der er en del anekdotisk evidens for, at folk i tredjeverdens lande, der ikke er vant til at blive præsenteret for billeder og visuelle repræsentationer enten ikke kan eller har meget svært ved at læse og fortolke selv simple tegneserier.

For det tredje så er det empiriske materiale, som Stjernfelt og Østergaard generaliserer ud fra, meget begrænset. Faktisk begrænser det sig til én kunstners værk inden for én bestemt genre, nemlig Carl Barks' Anders And historier. Dette forekommer at være en noget tynd base at opbygge en generel teori om handlingsrepræsentation i tegneseriemediet på. Stjernfelt og Østergaard anerkender selv dette problem i en note (note 7), hvor de indrømmer, at de hovedsageligt fokuserer på "den klassiske tegneserie (børnetegneserien om man vil)" og erkender at "man kan sagtens finde eksempler fra den mere avantgardistiske tegneserie, der bryder med de principper vi her nævner. Det svarer til at man indenfor poesien kan finde eksempler, der ikke følger almindelige regler for kommunikation" (s. 135).

Dette forekommer at være et noget spinklelt forsvar. Dels så virker det som "begging the question" på forhånd at betragte tegneserier, der ikke overholder Stjernfelt og Østergaards principper for handlingsrepræsentation, som avantgardistiske og afvigende fra normalen. Og dels så er det uklart, præcist hvad Stjernfelt og Østergaard vil betegne som "avantgardistisk" indenfor tegneseriemediet. Voksen tegneserier som sådan (Og hvad er voksentegneserier?) Chris Ware? Brødrene Hernandez? Grant Morrisons Flex Mentallo? Frank Millers Dark Knight Returns? 
De fire artikler, der er samlet under den fælles overskrift "Tegneseriens æstetik" repræsenterer kort sagt fire vidt forskellige tilgange til studiet af tegneserier. Det eneste der umiddelbart forener dem er, at de beskæftiger sig med det samme medie, nemlig tegneserier. Derudover adskiller de sig i valg af emne, teoretisk tilgang, skrivestil og konkrete eksempler som de beskæftiger sig med. Og det er nok meget sigende for tegneserieforskningen lige nu. Den galopperer af sted $i$ alle mulige forskellige retninger $i$ takt med at tegneseriemediet selv i netop disse år udvikler sig og bliver stadig mere alsidigt og uforudsigeligt

Det er tvivlsomt, om der er nogen af Kritiks læesere, der finder alle artiklerne interessante, men omvendt så sikrer den tematiske spredning, at alle der plejer at kigge i Kritik nok skal finde mindst en artikel, som de har interesse i. Personligt vil jeg da i særdeleshed anbefale, at man kigger nærmere på artiklerne om tegneserier og tegneserieforskning. Dels fordi tegneserier er et af mine egne interessefelter, men også fordi forskningen $\mathrm{i}$ tegneserier i disse år er ved at etablere sig som en selvstændig og interessant disciplin.

Carsten Fogh Nielsen 